Annals of Tropical Research 30[2]:22-33(2008)

(c) VSU, Leyte, Philippines

\title{
Somatic embryogenesis and plant regeneration in purple food yam (Dioscorea alata L.)
}

\author{
Marilyn M. Belarmino ${ }^{1}$ and Jocelyn R. Gonzales ${ }^{2}$ \\ ${ }^{1}$ Department of Horticulture, College of Agriculture, Visayas State University, Visca, \\ Baybay, Leyte 6521-A, Philippines; \\ ${ }^{2}$ Laboratory of Vegetable Science, Faculty of Horticulture, Chiba University, 648 \\ Matsudo, Matsudo City, Chiba 271-8510, Japan
}

\begin{abstract}
A study was conducted to establish a reliable procedure for somatic embryogenesis and plant regeneration from callus cultures of purple food yam (Dioscorea alata L.). The procedure involved three steps; (1) culture of nodal stem segments from greenhousegrown plants to generate in vitro plantlets; (2) induction of callus from the leaf, petiole and nodal stem tissues; and (3) initiation of somatic embryo from callus. Results showed that the agar-solidified Murashige and Skoog (MS) medium containing $30 \mathrm{gl}^{-1}$ sugar, $0.1 \mathrm{gl}^{-1} \mathrm{a}$-cysteine , $10 \mathrm{mgl}^{-1}$ calcium pantothenic acid, $2.0 \mathrm{mgl}^{-1}$ asparagine, $2.0 \mathrm{mgl}^{-1}$ arginine, $80.0 \mathrm{mgl}^{-1}$ adenine sulfate $\left(\mathrm{AdSO}_{4}\right)$ and $0.1 \mathrm{mgl}^{-1}$ naphthalene acetic acid (NAA) effectively broke dormancy of lateral buds of nodal stem cultures from both 'VU-2' and 'Kinampay' varieties. Production of multiple adventitious shoots occurred after transfer of in vitro nodal pieces to the same medium added with $1.0 \mathrm{mgl}^{-1}$ benzylamino purine (BAP) or, MSA medium. Callus was effectively induced from the vegetative tissues in MS medium added with $1.0 \mathrm{mgl}^{-1}$ 2,4-Dichlorophenoxy acetic acid (2,4-D) or, with picloram. Among the three types of explants, the nodal stem was the most suitable which produced purplish nodular embryogenic callus. A higher percentage of nodal stem-derived calli produced globular embryos in MS medium containing $1.0 \mathrm{mgl}^{-}$ ${ }^{1}$ 2,4-D and $0.5 \mathrm{mgl}^{-1} \mathrm{BAP}$, or in $1.0 \mathrm{mgl}^{-1}$ picloram and $0.5 \mathrm{mgl}^{-1} \mathrm{BAP}$ than, in the plant growth regulator-free medium (control). The maturation of embryos was facilitated by one-month culture in MS medium containing $0.1 \mathrm{mgl}^{-1} \mathrm{ABA}$ and $100 \mathrm{mgl}^{-1}$ glutamine. This step improved the germination of somatic embryos in one-half strength PGR-free MS medium containing $100 \mathrm{mgl}^{-1}$ glutamine (regeneration medium). All somatic embryoderived plantlets were morphologically normal and established well in soil.
\end{abstract}

Keywords: callus, multiple adventitious shoots, nodal stem explant, plantlet, somatic embryo

Correspondence: M. M. Belarmino Address: AVRDC-The World Vegetable Center, Regional Center for Africa, P.O.Box 10, Duluti, Arusha, Tanzania.E-mail:marilyn.belarmino@worldveg.org Tel No. +25527 2553093/2553102 Fax No. +255272553125

DOI: $10.32945 /$ atr3022.2008 


\section{INTRODUCTION}

Aromatic purple varieties of greater yam (Dioscorea alata L.) are among the important food yams that are highly sought because of their culinary value. Despite their economic importance, however, production is still low due to limited supply of planting materials and lack of resistance to viral and fungal diseases (Saleil et al. 1990). Although in vitro multiplication of Dioscorea species has been performed using explants since 1980s (cited by Shu et al. 2005), this technique has not been routinely applied in purple yams due to tissue oxidation and necrosis.

So far, reports of de novo regeneration in D. alata were limited to callus derived from petiole explants (Fautret et al. 1985) and somatic embryos derived from root cells (Twyford and Mantell 1996) of white yams. Likewise, somatic embryogenesis has been reported in several Dioscorea species (Osifo, 1988; Twyford and Mantell 1996; Shu et al. 2005) but these did not include the purple yams. To date, the technical know how on the production of unlimited number of somatic embryos, which are uniform in size and shape and retain the capacity to give rise to normal plants, is not available for any species (Petrivica, 2004).

In this paper, we report the production of plants from purple varieties of $D$. alata through the induction of callus and somatic embryos using excised nodal stems of in vitro plants. The effects of plant growth regulators on adventitious shoot formation, callus induction, somatic embryo formation and plant regeneration are described.

\section{MATERIALS AND METHODS}

\section{Preparation of explants}

Greenhouse-grown plants ( 2 month-old) from two purple varieties of D. alata, 'VU-2' and 'Kinampay' (Type D, LA-609) were used as source of nodal stem explants for initial in vitro culture. Nodal explants were prepared from vines that were thoroughly washed with tap water and then soaked in $0.1 \%(\mathrm{v} / \mathrm{v})$ of fungicide solution (Benlate; Dupont, 
Wilmington, Delaware, USA) for $10 \mathrm{~min}$ followed by rinsing in sterile distilled water four times. Finally, the explants were surface sterilized in a commercial chlorine bleach solution (containing 4.5\% chlorine) for 20 minutes and then, rinsed four times in a sterile distilled water prior to cutting into single node stem pieces about 10-15 mm long.

\section{Culture medium and incubation condition}

The MS basal medium (Murashige and Skoog 1960) containing 30 $\mathrm{gl}^{-1}$ sugar (commercial white table sugar), $0.1 \mathrm{gl}^{-1} \alpha$-cysteine , $10 \mathrm{mgl}^{-1}$ calcium pantothenic acid, $2.0 \mathrm{mgl}^{-1}$ asparagine, $2.0 \mathrm{mgl}^{-1}$ arginine and 6 $\mathrm{gl}^{-1}$ agar (Pronadisa, Madrid, Spain) was used throughout this study. The $\mathrm{pH}$ of the medium was adjusted to 5.8 prior to autoclaving at $1.1 \mathrm{~kg} \mathrm{~cm}^{-}$ ${ }^{2}\left(121^{\circ} \mathrm{C}\right)$ for 20 minutes. Newly-inoculated explants were incubated in dark for one week followed by exposure to 16 hours of daylight (supplied by two pieces of $40-\mathrm{W}$ fluorescent tubes) at $26 \pm 1{ }^{\circ} \mathrm{C}$.

\section{Nodal stem culture of purple D. alata and adventitious shoot formation}

To break dormancy of lateral bud, nodal stems were inoculated individually in glass vial $(25 \mathrm{~mm} \times 95 \mathrm{~mm})$ containing $10 \mathrm{ml}$ of medium. The medium was supplemented with $1.0 \mathrm{mgl}^{-1} \mathrm{BAP}$ and $0.1 \mathrm{mgl}^{-1} \mathrm{NAA}$ $\left(\mathrm{T}_{1}\right) ; 2.0 \mathrm{mgl}^{-1} \mathrm{BAP}$ and $0.1 \mathrm{mgl}^{-1} \mathrm{NAA}\left(\mathrm{T}_{2}\right) ; 80 \mathrm{mgl}^{-1}$ adenine sulfate $\left(\mathrm{AdSO}_{4}\right.$ ) and $0.1 \mathrm{mgl}^{-1} \mathrm{NAA}\left(\mathrm{T}_{3}\right) ; 100 \mathrm{mgl}^{-1} \mathrm{AdSO}_{4}$ and $0.1 \mathrm{mgl}^{-1} \mathrm{NAA}$ $\left(\mathrm{T}_{4}\right.$ ). The medium lacking plant growth regulators (PGR) served as control $\left(\mathrm{T}_{0}\right)$. Twenty-five explants were inoculated for each treatment and replicated four times. All nodal cultures were kept in dark for one week and then exposed to $16 \mathrm{~h}$ photoperiod for further eight weeks. The explants were transferred to fresh medium at one week interval until lateral bud break and shoot emergence.

\section{Induction of multiple adventitious shoots}

Nodal stem-derived shoots containing at least four nodes were cut into single node stem pieces and inoculated vertically in one-half strength 
MS medium to induce multiple adventitious shoot formation. The first medium, MSA was supplemented with $1.0 \mathrm{mgl}^{-1} \mathrm{BAP}, 80 \mathrm{mgl}-1 \mathrm{AdSO}_{4}$ and $0.1 \mathrm{mgl}^{-1} \mathrm{NAA}$ and the other, MSB was added with $1.0 \mathrm{mgl}^{-1} \mathrm{BAP}$ and $0.2 \mathrm{mgl}^{-1} \mathrm{NAA}$. The MS medium without plant growth regulator served as control (MSC). Five single node stem pieces were inoculated per culture bottle $(60 \mathrm{~mm} \times 120 \mathrm{~mm})$ containing $30 \mathrm{ml}$ of medium. Fifty nodal stem pieces were inoculated for each treatment and replicated four times. All nodal cultures were kept under $16 \mathrm{~h}$ photoperiod at $25 \pm 1{ }^{\circ} \mathrm{C}$. The percentage of nodal explants producing multiple shoots and the average number of shoots produced per nodal explant were determined after four weeks of culture. The nodal stem-derived shoots were maintained by transferring them to fresh medium at one month interval.

\section{Induction of callus from vegetative tissues}

Stem (5 mm long), leaf ( $5 \mathrm{~mm} \times 5 \mathrm{~mm})$, and petiole $(5 \mathrm{~mm}$ long) pieces obtained from one month old in vitro plantlets of 'Kinampay' and 'VU-2' were evaluated for callus formation using $1.0 \mathrm{mgl}^{-1}$ of 2,4-D, NAA, and picloram that were added individually into the MS medium. The medium without PGR served as control. The most suitable type of explant (i.e., nodal stem) and PGR (i.e., 2,4-D and picloram) was determined based on the highest percentage of callus formation. To improve the quality of callus, the experiment was repeated using $0.2,0.5,1.0$ and $2.0 \mathrm{mgl}^{-1}$ of 2,4-D and picloram. The quality of the callus was evaluated after two months. For both experiments, the explants were inoculated in glass vial $(25 \mathrm{~mm} \times 95 \mathrm{~mm})$ containing $15 \mathrm{ml}$ of treatment medium. Twenty-five explants were cultured per treatment medium and replicated four times. The explants were incubated in dark at $25 \pm 1{ }^{\circ} \mathrm{C}$ for one month and subcultured to fresh medium two times.

\section{Induction of somatic embryogenesis and regeneration of plants}

To initiate somatic embryo formation, the embryogenic calli derived from nodal stem explants were transferred into agar-solidified MS medium composed of macroelements with reduced ammonium nitrate $\left(800 \mathrm{mgl}^{-1}\right)$, microelements and vitamins at full concentration, $30 \mathrm{gl}^{-1}$ sugar, and $0.10 \mathrm{gl}^{-1} \alpha$-cysteine (initiation medium). The initiation medium 
was added with combinations of $1.0 \mathrm{mgl}^{-1} 2,4-\mathrm{D}$ and $0.5 \mathrm{mg} / \mathrm{L} \mathrm{BAP}\left(\mathrm{S}_{1}\right)$, or $1.0 \mathrm{mgl}^{-1}$ picloram and $0.5 \mathrm{mg} / \mathrm{LBAP}\left(\mathrm{S}_{2}\right)$. The medium without PGR served as control $\left(\mathrm{S}_{0}\right)$. Twenty calli ( $0.5 \mathrm{~g}$ fresh weight per callus) was inoculated for each treatment medium and incubated under $16 \mathrm{~h}$ photoperiod at $25 \pm 1{ }^{\circ} \mathrm{C}$. After two months, the calli containing globular somatic embryos were divided into small pieces $(0.2 \mathrm{~g}$ fresh weight per piece) and then, subcultured individually to agar-solidified MS medium containing $0.1 \mathrm{mgl}^{-1}$ of filter sterilized abscisic acid (ABA) and $100 \mathrm{mgl}^{-}$ ${ }^{1}$ glutamine (maturation medium). After one month, the percentage of calli pieces containing germinating embryos was evaluated. The germinating embryos were transferred to one-half strength PGR-free MS medium containing $100 \mathrm{mgl}^{-1}$ glutamine (regeneration medium) to increase the germination rate. The somatic embryo-derived plantlets were allowed to grow in this medium until the production of at least three leaves and five roots. The plantlets were acclimatized at room temperature for one wk and then, transplanted in a mixture of garden soil and river sand $(1: 1, \mathrm{v} / \mathrm{v})$ and maintained in the greenhouse. Percent survival of potted plantlets was determined one month after transplanting. All experiments were conducted following a completely randomized design. The analysis of samples from each treatment was evaluated using analysis of variance (ANOVA, $p<0.05 \%$ ).

\section{RESULTS AND DISCUSSION}

\section{Nodal stem culture of purple D. alata and adventitious shoot formation}

The nodal stem explants of $D$. alata showed darkening of the wounded tissue immediately after excision and exuded brown substance in the medium. Nodal stems of D. alata variety 'Kinampay' showed severe tissue browning compared to variety 'VU-2' that delayed the emergence of lateral bud found on the axil of the node. Among the treatment media, the medium containing $80.0 \mathrm{mgl}^{-1} \mathrm{AdSO}_{4}$ and $0.1 \mathrm{mgl}^{-}$

${ }^{1} \mathrm{NAA}\left(\mathrm{T}_{3}\right)$ broke dormancy of lateral buds and induced earlier emergence of shoot in 'VU-2' (30 days) and 'Kinampay' (51 days) compared to the 
Table 1. Formation of shoots from excised single nodal stem explants of $D$. alata varieties 'VU-1' and 'Kinampay' (KI) in agar-solidified Murashige and Skoog medium containing combinations of NAA and BAP, and adenine sulfate $\left(\mathrm{AdSO}_{4}\right)$ and NAA.

\begin{tabular}{|c|c|c|c|c|c|c|}
\hline \multirow[t]{2}{*}{$\begin{array}{l}\text { Treatments } \\
\left(\mathrm{mgl}^{-1}\right)\end{array}$} & \multicolumn{2}{|c|}{$\begin{array}{l}\text { Ave. no. of } \\
\text { days to bud } \\
\text { emergence }\end{array}$} & \multicolumn{2}{|c|}{$\begin{array}{l}\text { Percent shoot } \\
\text { emergence }\end{array}$} & \multicolumn{2}{|c|}{$\begin{array}{l}\text { Ave. no. of } \\
\text { shoots/nodal } \\
\text { explant }\end{array}$} \\
\hline & VU-2 & $\mathrm{KI}$ & VU-2 & $\mathrm{KI}$ & VU-2 & $\mathrm{KI}$ \\
\hline $\mathrm{T}_{0} ; 0.0$ & $52.0 \mathrm{a}$ & $60.0 \mathrm{~b}$ & $30.0 \mathrm{~b}$ & 0.0 & 1.0 & 0.0 \\
\hline $\mathrm{T}_{1} ; 1.0 \mathrm{BAP}+0.1 \mathrm{NAA}$ & $57.0 \mathrm{a}$ & $65.0 \mathrm{a}$ & $15.0 \mathrm{c}$ & 0.0 & 1.0 & 0.0 \\
\hline $\mathrm{T}_{2} ; 2.0 \mathrm{BAP}+0.1 \mathrm{NAA}$ & $\mathrm{nd}^{*}$ & nd & 0.0 & 0.0 & 0.0 & 0.0 \\
\hline $\mathrm{T}_{3}^{2} ; 80.0 \mathrm{AdSO}_{4}+0.1 \mathrm{NAA}$ & $30.0 \mathrm{c}$ & $51.0 \mathrm{~cd}$ & $50.0 \mathrm{a}$ & 30.0 & 2.0 & 1.0 \\
\hline $\mathrm{T}_{4}^{5} ; 100.0 \mathrm{AdSO}_{4}^{4}+0.1 \mathrm{NAA}$ & $37.0 \mathrm{~b}$ & $55.0 \mathrm{c}$ & $45.0 \mathrm{a}$ & 30.0 & 1.0 & 1.0 \\
\hline
\end{tabular}

*no data

other treatment media and the control (Table 1). $\mathrm{T}_{3}$ also induced the highest percentage of nodal explants with emerging lateral buds. Increasing the concentration of $\mathrm{AdSO}_{4}$ to $100 \mathrm{mgl}^{-1}\left(\mathrm{~T}_{4}\right)$ however, did not hasten bud emergence. Moreover, the medium containing $1.0 \mathrm{mgl}^{-1}$ $\mathrm{BAP}+0.1 \mathrm{mgl}^{-1} \mathrm{NAA}\left(\mathrm{T}_{1}\right)$ induced bud emergence but this took longer compared to the medium added with combinations of $\mathrm{AdSO}_{4}$ and NAA or, the control. Increasing the concentration of BAP to $2.0 \mathrm{mgl}^{-1}\left(\mathrm{~T}_{2}\right)$ resulted to the swelling of the lateral bud but did not hasten shoot emergence. Adenine sulfate belongs to the cytokinin group and known to induce shoot formation from excised plant tissues (George and Sherington, 1984). Likewise, NAA is an auxin that is reported to effectively induce shoot emergence when combined with an adenine derivative (Torres, 1989).

The three media: MSA, MSB and MSC (control) induced adventitious shoot formation from in vitro-derived nodal stem explants of 'Kinampay' and 'VU-2'. MSA medium was the most effective for both varieties since it initiated rapid lateral bud emergence (14.0 days in 'Kinampay' and 12.4 days in 'VU-2'), produced the highest percentage of shoot formation (60\% in 'Kinampay' and $75 \%$ in 'VU-2') and the highest 


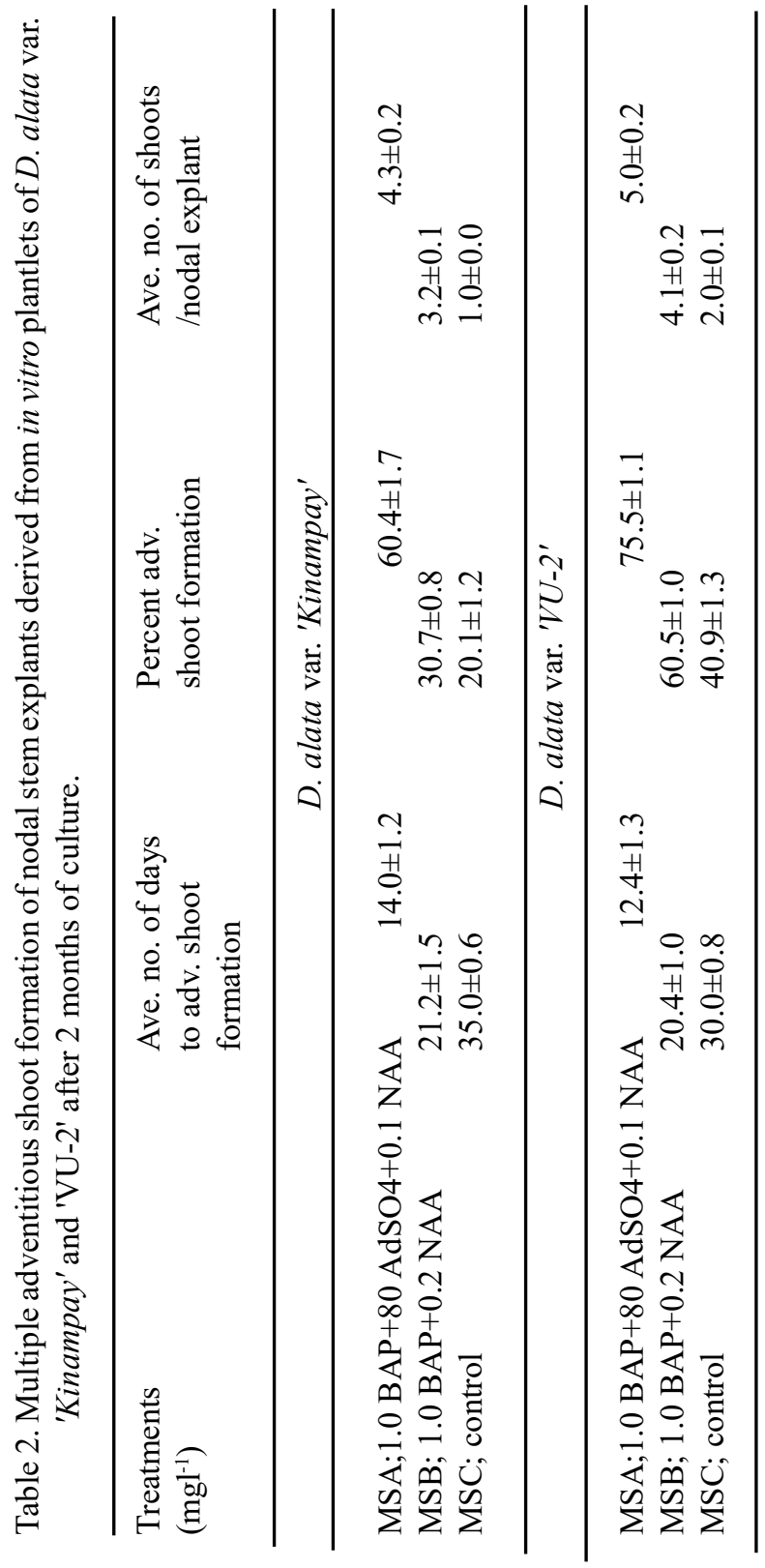






Figure 1. Percent callus formation from leaf, petiole and nodal stem explants of $D$. alata L. variety 'Kinampay' after two months of culture in agar-solidified MS medium containing $1.0 \mathrm{mgl}^{-1}$ of 2,4-D, NAA and picloram



Figure 2. Percent callus formation from leaf, petiole and nodal stem explants of $D$. alata

L. variety 'VU-2' after two months of culture in agar-solidified MS medium containing $1.0 \mathrm{mgl}^{-1}$ of 2,4-D, NAA and picloram. 
average number of shoots per nodal stem explant (4.3 shoots in 'Kinampay' and 5.0 shoots in 'VU-2') (Table 2). The multiple adventitious shoot formation was measured after two months of culture.

\section{Induction of callus and somatic embryogenesis}

2,4-D, NAA and picloram at $1.0 \mathrm{mgl}-1$ induced callus formation from leaf, petiole and nodal stem tissues of 'Kinampay' (Fig. 1) and 'VU$2^{\prime}$ (Fig. 2) after six weeks of culture in the dark. However, these explants did not form callus in the medium without PGR (control). The medium added with $1.0 \mathrm{mgl}^{-1} 2,4-\mathrm{D}$ or picloram induced higher percentage of explants that produced callus compared to $1.0 \mathrm{mgl}^{-1} \mathrm{NAA}$. Generally, 'VU-2' exhibited higher percentage of explants that produced callus compared to 'Kinampay'. Callus started forming around the edges of the cut area of explant tissue. Among the three types of explants, the nodal stem produced the highest percentage of purplish nodular embryogenic callus (Fig. 3A). In contrast, the leaf and petiole explants produced soft fine non-embryogenic calli that were highly vacuolated. More than 50\% of the leaf and petiole explants became totally brown and necrotic due to phenolic substances that were exuded from the cut portion (Thomas and Ravindra 1997). Tissue browning inhibits the production of callus and in severe cases led to the death of tissue (Waez, 1987; Taji and Williams 1996).

\section{Induction of somatic embryogenesis and regeneration of plants}

The embryogenic nodal-derived calli initiated somatic embryos (Fig. 3B) that appeared as purplish white globular structures after eight weeks of culture in the treatment media $\left(\mathrm{S}_{1}\right.$ and $\left.\mathrm{S}_{2}\right)$ and control $\left(\mathrm{S}_{0}\right)$. A higher percentage of calli produced globular embryos in the medium containing $1.0 \mathrm{mgl}^{-1} 2$,4-D and $0.5 \mathrm{mgl}^{-1} \mathrm{BAP}\left(\mathrm{S}_{1}\right)$, or $1.0 \mathrm{mgl}^{-1}$ picloram and 0.5 $\mathrm{mgl}^{-1}$ BAP $\left(\mathrm{S}_{2}\right)$ than in the control $\left(\mathrm{S}_{0}\right)$. The globular embryos underwent sequential stages of development and then germinated one month after transfer in PGR-free MS medium (Fig. 3C). Embryo germination, however, was low (12-20\%) due to slow embryo maturation. Hence, the embryos were cultured in maturation medium containing $0.1 \mathrm{mgl}^{-1} \mathrm{ABA}$ 

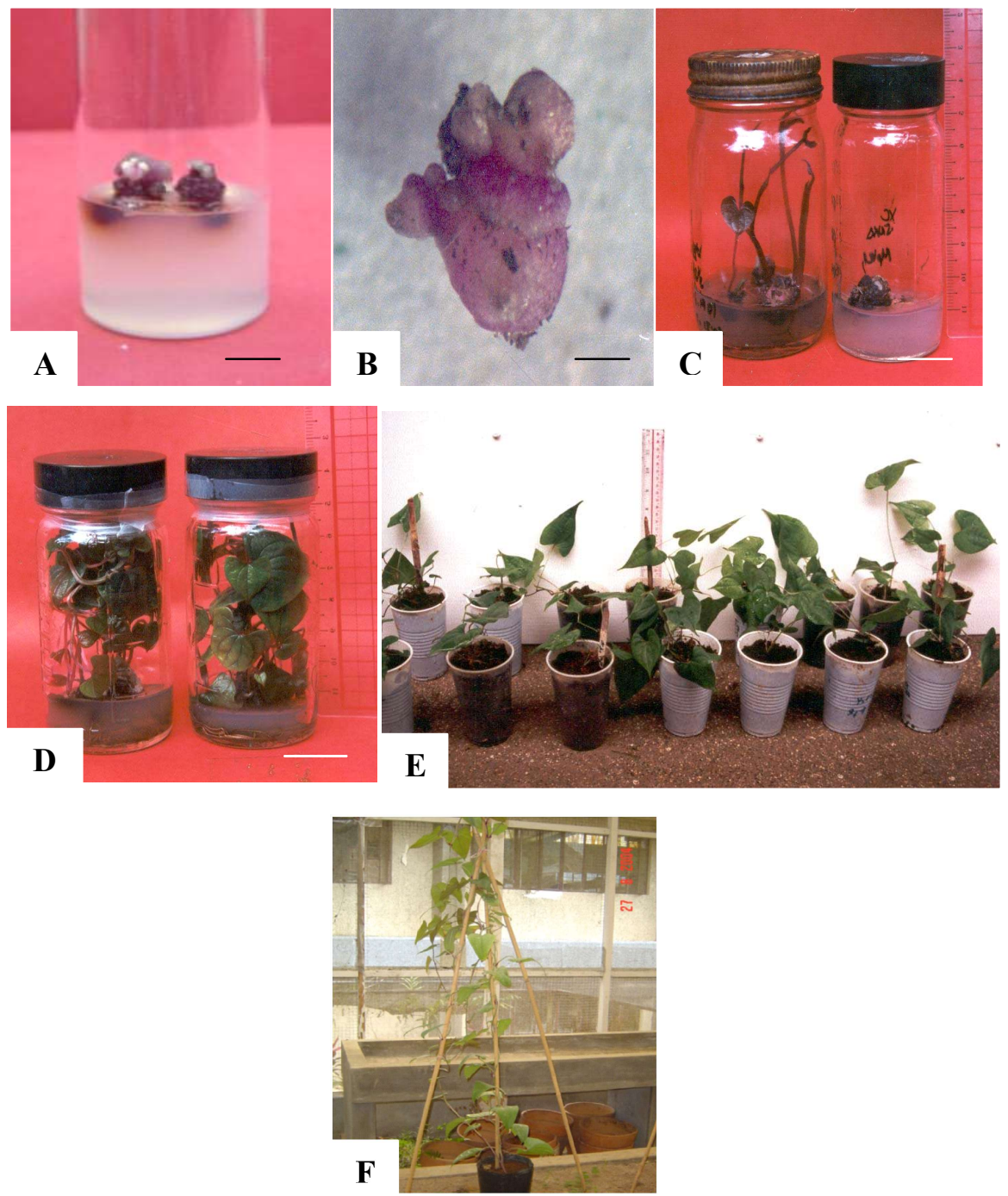

Figure 3. Induction of callus and somatic embryogenesis in purple D. alata L. (A) nodal

stem-derived calli, (B) somatic embryo, (C) germination of plantlet, (D) rooting

of plantlets, (E) potting of plantlets, and (F) establishment of plants in soil. (bar size; $A=5 \mathrm{~mm} ; B=1 \mathrm{~mm} ; C, D \& E=1 \mathrm{~cm} ; F=0.5 \mathrm{~m}$ ) 
and $100 \mathrm{mgl}^{-1}$ glutamine prior to transfer in the regeneration medium. This step improved the germination of somatic embryos. ABA effectively normalized the development of embryos and fostered normal maturation (Ammirato, 1983). Forty-five and sixty-two percent of ABA-treated somatic embryos of 'Kinampay' and 'VU-2', respectively, were converted to plantlets after three weeks of culture in regeneration medium containing $100 \mathrm{mgl}^{-1}$ glutamine (Fig. 3D). The beneficial effects of glutamine for plant regeneration were also reported in the explants of Dioscorea composita Hemsl. and D. cayenensis Lam., D. composita and D. cayensis (Viana and Mantell 1988). The regenerated plantlets were transplanted in soil (Fig. 3E), established well in the greenhouse (Fig. 3F)) and produced one to two tubers setts at 20-40 g per tuber sett.

The present study, therefore, presents a method for plant regeneration via the induction of somatic embryos from excised nodal stems. The ability to control somatic embryogenesis in purple yams is a necessary requisite for the development of an efficient biotechnological tool with applications in rapid mass clonal propagation, genetic transformation, artificial seed production and cryopreservation.

\section{LITERATURE CITED}

FAUTHERET, A., P. DUBLIN and P. CHAGVARDIEFF. 1985, Callus formation and neoformation with two edible Dioscorea species: D. alata and D. trifida (pp 624-632). Proc. 7th Symp. Intl. Soc. Trop. Root Crops, INRA, Guadaloupe.

GEORGE, E.F. and P.D. SHERINGTON. 1984. Plant propagation by tissue culture. Reading, Berks Eastern Press.

MURASHIGE, T. and F. SKOOG 1962. Arevised medium for rapid growth and bioassays with tobacco tissue cultures. Physiol. Plant. 15: 473-492

OSIFO, E. O. 1988. Somatic embryogenesis in Dioscorea. Plant Physiol. 133:378-380

PETREVICA, L. 2004. Micropropagation in horticultural and tropical plant production. Pure State Horticultural Research Station Tukuma r.; LV-3124; LATVIA. IITA Crops and Farming Systems

SALEIL, V., L. DEGRAS and R. JONARD. 1990. Obtention de plantes indemnes du virus de la mosaïque de l'igname (YMV) par culture in vitro des apex chez l'igname americaine Dioscorea trifida L. Agronomie, 10: 605-615. 
SHU, Y., Y. YING-CAI and L. HONG-HUI. 2005. Plant regeneration through somatic embryogenesis from callus cultures of Dioscorea zingiberensis. Plant Cell Tiss. Org. Cult. 80(2): 157-161(5)

TAJI, A. and R. WILLIAMS. 1996. Tissue culture of Australian plants. Armidale, NSW: University of England

THOMAS, P. and M. B. RAVINDRA. 1997. Effects of pruning or removal of in vitro formed roots on ex vitro regeneration and growth in micropropagated grapes. Plant Cell Tiss. Org. Cult., Dordrecht, 51(3): 177-180

TORRES, K.C. 1989. Tissue culture techniques for horticultural crops. AVI Books, New. York

TWYFORD, C. T. and S. H. MANTELL. 1996. Production of somatic embryos and plantlets from root cells of the Greater Yam. Plant Cell Tiss. Org. Cult. 46: 17-26

VIANA, A. M. and S. H. MANTELL. 1989. Callus induction and plant regeneration from excised zygotic embryos of the seed-propagated yams Dioscorea composita Hemsl. and D. cayenensis Lam. Plant Cell, Tiss. Org. Cult. 6(2):113-122

WAEZ ,V. J. 1987. The effect of activated charcoal on in vitro propagation of eestern European orchids. Acta. Horticulture. 1: 131-138. 